\title{
粉末製造技術とその応用 \\ Powder Manufacturing Technology and Its Application
}

\author{
新見 義朗 \\ Yoshiro ARAMI
}

福田金属䇴粉工業（株）

Fukuda Metal Foil \& Powder Co. Ltd.,

本特集では金属粉からセラミックス粉, さらにはそれらの 複合粉に至る幅広い種類の粉末の製造技術およびそれら粉末 の応用に関して幅広く議論することを目的として講演を募集 した。その結果，アトマイズ法から湿式法に至る様々な粉末 製造技術，並びにそれら製造技術によって得られたミクロン レベルからナノレベルに至る様々なサイズおよび種類の粉末 の特性に関する研究成果をはじめ, 応用面においても粉末の 成形性や焼結性改善のための新たな技術や様々な機能材料あ るいは最近注目を集めている $3 \mathrm{D}$ 積層造形への応用等に関す る研究成果も含め, 特別講演 1 件, 招待講演 1 件, 一般講演 13 件, 受賞記念講演 1 件の計 16 件の講演が行われ, 活発な 議論が交わされた，以下，講演内容について概説する。

まず，特別講演では，長年，鉄系焼結部品用原料粉の開発 に携わってこられた九州大学 尾崎氏による「粉末治金製品 高付加価值化に向けた原料粉末特性制御とその可能性」なる 題目の講演が行われ，1）原料粉末の金型充填性の改善，2） 高圧粉密度の実現，3）局所的歪集中の緩和，等の方策につ いて紹介するとともに, これからの製品開発のあり方とし て，これまでの開発成果をデータベースし，これらを共有お よび活用しつつ, 原料粉開発, 部品製造技術開発が一体化し た製品開発が必要であるとの提言がなされた.

招待講演では「コールドスプレーで作製した高力黄銅皮膜 の評価」と題して福田金属䇴粉工業 西村氏がコールドスプ レーの特徵, ならびに高力黄銅粉末の成膜性検討の一環とし て, 粒子圧縮強度と粉末の付着率との関係を示し, 熱処理に よる粒子圧縮強度の低減が付着率向上に繋がることを示し た.コールドスプレーでは粉末治金法で焼結が困難であった 高力黄銅粉でも成膜可能であるため, $3 \mathrm{D}$ 積層造形法ととも に粉末治金用原料粉末の新たな用途展開の場となる可能性が 高く，今後の技術開発が期待される.

一般講演は概略，1）ナノ粒子および微細金属粉の製造技 術，2）複合ナノ粒子, ナノファイバーの製造技術，3）レー ザー積層造形を含めた成形・焼結技術, の三つのセッション
に分かれ講演発表が行われた。1）では，高圧水アトマイズ による微細銀粉の製造技術（大研化学製造販売 萩原氏，久 保氏）から新規銅錯体溶液を用いた銅ナノ粒子の作製（福田 金属箔粉工業 上林氏）や回転 CVD 法による Niナノ粒子触 媒の作製（住友金属鉱山 中倉氏），さらには有機質前駆体か らの炭化チタン粉末の合成（物材機構西村氏）といった様々 な粉末製造技術の紹介がなされた。一方，2）では，CNTを 応用した複合粒子の作製に関した報告が 3 件（名古屋工大 Peng 氏, 東北大 角田氏, 東北大 菊池氏）あり, CNT の多様 な特徴を生かした応用技術の進展がうかがえた。また，豊橋 技科大 辰巳氏は「静電相互作用を利用した複合粒子連続製 造技術」と題して，Y 型チャンネルを有するフローリアクタ を用いて局所混合することで母粒子と子粒子をそれぞれ相反 する電荷に調整し, 次に各々の粒子の懸濁液を上記 $Y$ 型チャ ンネル合流部のすぐ下流側にホール部を有するリアクタに通 すことで母粒子表面に子粒子が均一に付着した複合粒子を 連続的に製造可能な複合化デバイスを紹介した。ささらに3） では, Ti-6Al-4V 粉末のレーザー積層造形に関する 2 件の講 演（芝浦工大 宮崎氏, および物材機構 草野氏）と, 難焼結 性 $\mathrm{Cu}-\mathrm{Al}$ 系合金粉末の焼結性改善（福田金属箔粉工業 宮川 氏）並びに鉄系成形体の強度に及ぼす樹脂添加の影響（JFE スチール 宇波氏）に関する講演が行われ，いずれのセッショ ンでも活発な討論が交わされた.

協会賞受賞記念講演では福田金属箔粉工業 新見が「高性 能銅系焼結部品用原料粉末に開発」なる題目で講演を行っ た。講演では新たに開発された $\mathrm{Al}$ 青銅系粉末および $\mathrm{Ni}$ 青銅 系粉末の 2 種類の銅系粉末を用いた焼結体の優れた性能が示 され，今後の新たな銅系焼結部品市場の掘り起こしが期待さ れる.

最後に，本講演特集で貴重な研究成果をご講演いただきま した方々，並びに活発にご討論いただきました参加者の方々 には改めて厚く御礼申し上げます。 